\title{
Profitability Performance And Firm Size-Growth Relationship
}

Arun Mukhopadhyay, Saint Mary’s University, Halifax, Canada

Sal AmirKhalkhali, Saint Mary's University, Halifax, Canada

\begin{abstract}
In this study, we intend to examine empirically how a firm's profitability performance would impact its growth process and what implications follow for the validity of Gibrat's law. The basic thesis that is tested in this study is that smaller firms, being more constrained in obtaining outside funds for growth, can possibly show a higher propensity to growth when their internally generated profits are high. To this end, we apply a dynamic model to panel data on a sample of firms in the USA. We first investigate the size-growth relationship for the whole sample, and then, these firms are classified into three profitability performance groups on the basis of the average size of profits as percentage of stock-holders' equity. The empirical results emanating from this study are mixed, with the dominant result that in many cases, larger firms grow faster, violating Gibrat's law. Moreover, the results do not lend visible support to the hypothesis that higher profitability confers a growth advantage to the smaller firms.
\end{abstract}

Keywords: firm size- growth, profitability, and Gibrat's law

\section{INTRODUCTION}

ibrat (1931) demonstrated that the skewed distributions of enterprise and plant sizes in the French manufacturing establishments can be explained very well by a random growth process. This assumption of random growth has been subsequently christened the "Gibrat's law". Gibrat's law implies that with a random growth process, the expected growth rate is independent of a firm's size and other identifiable firm and industry characteristics. Within this context, the issue of whether firm size has a systematic influence on the growth rate of a firm has been the subject of extensive investigation in empirical studies, partly because this size-growth relation is most directly involved in explaining the size-distribution of firms. Following Simon (1955), several studies have used the Gibrat's law to explain the firm size-distribution of the large firms in the United States. See, for instance, Iriji and Simon (1974), Chesher (1979), Vining (1976), Wagner (1992), AmirKhalkhali and Mukhopadhyay (1993), Almus and Nerlinger (2000), and Audresch et al. (2004). In general, empirical tests of the Gibrat's law so far have not provided very clear evidence for or against it. See, for instance, Chesher (1979), Droucopoulos (1982, 1983), Buckley, Dunning, and Pearce (1984), Kumar (1985), Hall (1987), Hart and Oulton (1996), Sutton (1997), Caves (1998), Del Monte and Papagni (2003), Mukhopadhyay and AmirKhalkhali (2004), Bottazzi and Secchi (2006) and Coad (2007) for discussions on the firm's growth theory and empirical studies.

In this study, we investigate the role of profit in influencing the growth of firms and, in particular, the sizegrowth relationship. To begin with, we note that there is considerable evidence that profit rates of firms can persist over time, and secondly, a higher profit is likely to help a firm grow faster. We then argue that the facilitating role of profit in generating growth is likely to be more important for the smaller firms who have less access to capital markets than the larger ones who can more easily obtain borrowed funds or new equity capital.

A considerable amount of evidence has accumulated over time that above-normal profits are not essentially temporary and quickly eroded by competitive forces. Mueller (1977), for example, finds evidence of persistently high profits for US firms over a period of 24 years. Mueller argues that companies use the current high profits to protect future profits, using various means. "Some companies erect entry barriers through increased product differentiation, others via scarce natural resources or land sites. Some obtain legal protection for their positions (e.g., patents, tariffs, licenses) by purchasing the services of scientists or technicians, lawyers or lobbyists, or more 
directly by contributions to politicians and public officials themselves. The means vary, but the ends are the same, the preservation of an existing monopoly rent" (p.370). This is an endogenous theory of the persistence of profit, but it is consistent with theories and empirical studies relating persistently high profit rates to market structure variables. Shepherd (1975), for example, finds high and stable market shares to be associated with profits.

The relationship between profit and growth seems obvious: profit provides the funds for growth. A firm can grow internally through investments in development projects in various ways. For example, it can grow by taking advantage of internal economies of scale, or product and industry diversification, or geographical expansion at home and abroad. It can take advantage of technological opportunities to grow through research and development, leading to product and process innovations. Or, it can grow through mergers and acquisitions. But, in all these cases, availability of internal funds makes it easier for a firm to undertake the growth projects. Even though a part of the capital for expansion may be obtained by borrowing, the availability and cost of external funding would generally be lower when a greater proportion of the funding is internal.

Moreover, the separation of ownership and control of firms creates a bias towards using the profits for the purpose of growth, as has been pointed out by Penrose (1959), Marris (1964) and many others (see Marris and Mueller (1980) for a review of this theory within a broader context). The bias is created because managers, acting in their own self-interest, would not care as much for paying dividends to the shareholders as they would for plowing back the profit into the firm in pursuit of growth. This is likely to create a faster rate of growth for the firm than is optimal for the owners (the shareholders) of the company. Penrose (1959) extends this thesis of bias towards growth even to the case of owner-mangers, pointing out that small businessmen view their companies as their life's work and find fulfillment of their entrepreneurial quest through growth of their businesses.

This facilitating effect of internal funding generated from retained earnings out of the profits earned by a company is likely to be more important for the smaller companies. Information asymmetries and perceived risk are more pronounced for smaller firms affecting availability of credit, thus highlighting the importance of internal funds, compared to the larger firms. [See, for example, Binks and Ennew (1996), Carpenter and Petersen (2002), and Beck et. al. (2005)]. This leads to the hypothesis that the positive effect of profit on growth is more pronounced for the smaller firms than the larger ones.

\section{THE DATA, MODEL AND THE EMPIRICAL RESULTS}

The sample used in this study consists of data for the same 191 firms maintaining their identity over the 2000-2007 period. These firms are chosen from various issues of the Fortune 500 largest industrial firms in the USA. The firms are classified into three profitability groups on the basis of their profitability performance measured by the average size of profits as percentage of stock-holders' equity over the 2000-2007 period. Table 1 gives the number of firms in each of three profitability groups (upper 25\%, middle 50\%, and lower 25\%) along with the average firm size (measured by real sales at 2000 prices) and growth rates of these firms and their variabilities measured by coefficient of variation (CV) over 2000-2003 and 2004-2007. It shows larger average size as well as higher growth rate for firms in the upper profitability group than those of the firms in the middle as well as lower profitability groups. The exception is the growth performance of the firms in the middle group that outperformed the other two groups over the 2004-2007 period.

Table 1

All Firms: Average Size and Growth Rates

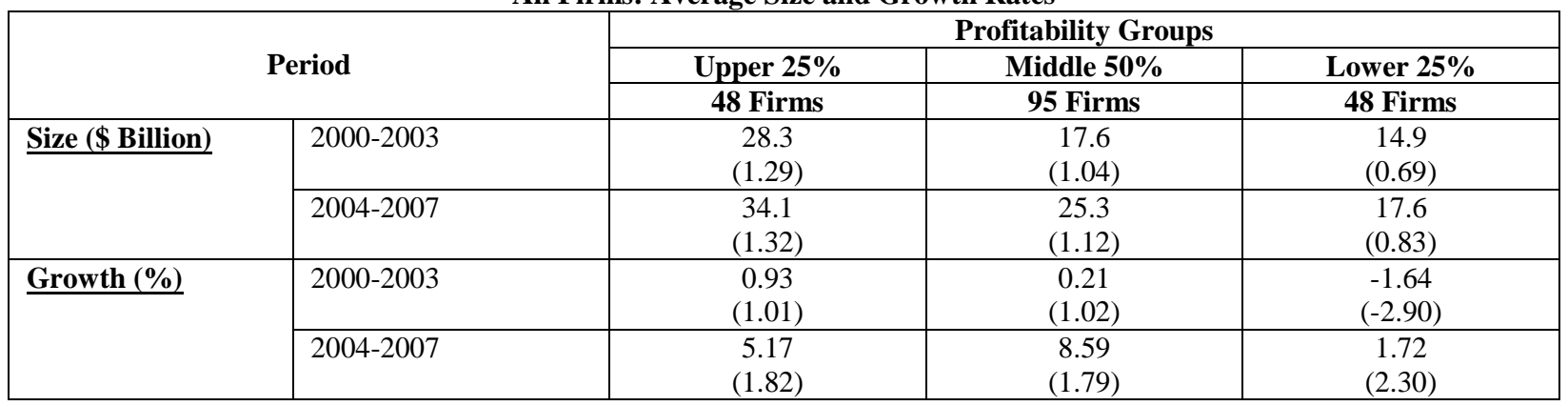

The figures in brackets are the corresponding coefficients of variation. 
The empirical model used in this study follows the method developed by Chesher (1979):

$$
\mathrm{Y}_{\mathrm{it}}=\gamma_{1} \mathrm{Y}_{\mathrm{it}-1}+\gamma_{2} \mathrm{Y}_{\mathrm{it}-2}+\mathrm{u}_{\mathrm{it}}
$$

where $Y_{\text {it }}$ represents the deviation of the logarithm of the size of the $i^{\text {th }}$ firm from the mean of the logarithms of the sizes of firms at time t. $\gamma_{1}$ and $\gamma_{2}$ are parameters, and $\mathrm{u}_{\mathrm{it}}$ is the disturbance term. $\mathrm{Y}_{\mathrm{it}-1}$ and $\mathrm{Y}_{\mathrm{it}-2}$ are the one-and two-period lagged values of $Y_{i t}$, respectively.

The above dynamic model can be used to conduct direct test concerning the Gibrat's law of Proportionate Effect, by estimating the two parameters. If $\gamma_{1}=1$ then firm growth is independent of its size. If $\gamma_{1}<1$ we expect smaller firms to grow faster, and if $\gamma_{1}>1$ then bigger firms are expected to have the advantage of faster growth. Further, rejecting the hypothesis $\gamma_{2}=0$ would imply that the disturbances $\mathrm{u}_{\mathrm{it}}$ are autocorrelated, The Gibrat's law will not hold even if $\gamma_{1}=1$ but the disturbances $\mathrm{u}_{\mathrm{it}}$ are autocorrelated. Accordingly, the law holds if $\gamma_{1}=1$ and $\gamma_{2}=0$.

While the issue of autocorrelation might have been addressed by the above autoregressive model, the problem of heteroscedasticity would remain to be addressed. This is an important issue in this cross-sectional study over successive time periods, due to the managerial and other firm-and/or industry-specific differences across the firms as well as economic, technological and other changes over time. Another major difficulty associated with the specification of the above fixed coefficients model is that, this model would not relate the response variable to its determinants properly if the latter were correlated with the corresponding disturbance term. In particular, if the disturbance is viewed as the impact of excluded variables that along with the included variables is sufficient to determine the response variable neither the slope coefficients nor the disturbance term are unique, and the former cannot be viewed as measuring the effects on this variable. Furthermore, even an instrumental variables approach would not help in that if the included variables are not generically independent of the disturbance term, these estimators would, in general, be inconsistent as shown by Pratt and Schlaifer $(1984,1988)$.

Accordingly, we approach the specification and estimation using the manner developed by AmirKhalkhali and Dar (1993). To this end, our study extends the model (1) in the following way:

$$
\mathrm{Y}_{\mathrm{it}}=\gamma_{1 \mathrm{it}}+\gamma_{2 \mathrm{it}} \mathrm{Y}_{\mathrm{it}-1}+\gamma_{3 \mathrm{it}} \mathrm{Y}_{\mathrm{it}-2}+\mathrm{w}_{\mathrm{it}}
$$

Note that (2) is a varying coefficients model, and that the disturbance term would be now viewed as the joint effect of the remainder of excluded variables after the effect of included variables on these excluded variables has been subtracted out. Further, whereas the explanatory variables cannot be uncorrelated with every variable that affects the dependent variable, they can be uncorrelated with the remainder of every such variable. For details, see Pratt and Schlaifer (1984, 1988), and AmirKhalkhali and Dar (1993).

In order to investigate the effects of profitability on the size-growth relationship, the firms in our sample are classified into three groups on the basis of the relative size of profitability (upper $25 \%$, middle $50 \%$, and lower 25\%). These group-wise size-growth relations are estimated over time. Accordingly, we specify six sets of varying coefficients regression models: (i) $\mathrm{Y}_{2002}$ on $\mathrm{Y}_{2001}$ and $\mathrm{Y}_{2000}$, (ii) $\mathrm{Y}_{2003}$ on $\mathrm{Y}_{2002}$ and $\mathrm{Y}_{2001}$, (iii) $\mathrm{Y}_{2004}$ on $\mathrm{Y}_{2003}$ and $\mathrm{Y}_{2002}$, (iv) $\mathrm{Y}_{2005}$ on $\mathrm{Y}_{2004}$ and $\mathrm{Y}_{2003}$, (v) $\mathrm{Y}_{2006}$ on $\mathrm{Y}_{2005}$ and $\mathrm{Y}_{2004}$, and (vi) $\mathrm{Y}_{2007}$ on $\mathrm{Y}_{2006}$ and $\mathrm{Y}_{2005}$. These models are estimated using random generalized least squares (RGLS) estimators. For more details of the varying coefficients estimation techniques, see Swamy (1970), Swamy and Mehta (1975), and Swamy and Tavlas (1995, 2002).

Table 2 shows the RGLS estimation results for all firms in the sample taken as a whole, and for each period. The superscripts (1+), (1-), (1), and (*) on estimated coefficients denote statistically greater than one, less than one, not different from unity, and significant at the $5 \%$ level, respectively. These pooled results support the Gibrat's law over the first three periods 2002, 2003, and 2004. However, they refute the Gibrat's law in the next three periods. For 2005 and 2006, the results imply faster growth for larger firms $\left(\gamma_{1}>1\right)$ and also autocorrelated growth. For 2007, the Gibrat's law does not hold because of autocorrelated growth. 
Table 2

Pooled Varying Coefficients Results, All Firms

The Model: $\mathbf{Y}_{\mathrm{it}}=\gamma_{1 \mathrm{t}} \mathbf{Y}_{\mathrm{it}-\mathrm{l}}+\gamma_{2 \mathrm{t}} \mathbf{Y}_{\mathrm{it}-2}+\mathbf{u}_{\mathrm{it}}$

\begin{tabular}{|c|c|c|c|c|}
\hline $\begin{array}{c}\text { Period } \\
(\mathbf{t})\end{array}$ & $\mathbf{Y}_{\mathbf{i t}}$ on $\mathbf{Y}_{\mathbf{i t - 1}}$ \& $\mathbf{Y}_{\mathbf{i t - 2}}$ & $\boldsymbol{\gamma}_{\mathbf{1 t}}$ & $\boldsymbol{\gamma}_{\mathbf{2 t}}$ & $\mathbf{R}^{\mathbf{2}}$ \\
\hline $\mathbf{2 0 0 2}$ & $\mathrm{Y}_{2002}$ on $\mathrm{Y}_{2001} \& \mathrm{Y}_{2000}$ & $0.936^{*}{ }^{* 1}$ & 0.039 & 0.943 \\
\hline $\mathbf{2 0 0 3}$ & $\mathrm{Y}_{2003}$ on $\mathrm{Y}_{2002} \& \mathrm{Y}_{2001}$ & $1.041^{* 1}$ & -0.038 & 0.972 \\
\hline $\mathbf{2 0 0 4}$ & $\mathrm{Y}_{2004}$ on $\mathrm{Y}_{2003} \& \mathrm{Y}_{2002}$ & $1.063^{* 1}$ & -0.058 & 0.977 \\
\hline $\mathbf{2 0 0 5}$ & $\mathrm{Y}_{2005}$ on $\mathrm{Y}_{2004} \& \mathrm{Y}_{2003}$ & $1.460^{* 1+}$ & $-0.488^{*}$ & 0.980 \\
\hline $\mathbf{2 0 0 6}$ & $\mathrm{Y}_{2006}$ on $\mathrm{Y}_{2005} \& \mathrm{Y}_{2004}$ & $1.342^{* 1+}$ & $-0.347^{*}$ & 0.988 \\
\hline $\mathbf{2 0 0 7}$ & $\mathrm{Y}_{2007}$ on $\mathrm{Y}_{2006} \& \mathrm{Y}_{2005}$ & $1.293^{* 1}$ & $0.110^{*}$ & 0.972 \\
\hline
\end{tabular}

(*): significantly different from zero at the $5 \%$ level.

(1): significantly not different from unity at the $5 \%$ level.

(1+): significantly greater than unity at the $5 \%$ level.

To assess whether and to what extent these pooled results mask differences among the firms in the three profitability groups, we look at the profitability group-specific estimates of the model. These estimates are reported in Table 3. The results support the Gibrat's law over the first two periods 2002and 2003 for all three profitability groups. However, the results are mixed for 2004 period. In the case of upper group of profitability, the 2004 results support Gibrat's law. Nevertheless, these results indicate persistent growth for the middle group, and faster growth for larger firms in the case of lower group of profitability. For the last three years, all results point to faster growth for larger firms. The significance of the calculated GSTAT indicate the validity of the varying coefficients approach for distinguishing these three groups in four of our six periods.

Table 3

Profitability Group-Wise Varying Coefficients Results, All Firms

The Model: $\mathbf{Y}_{\text {it }}=\gamma_{1 \mathrm{t}} \mathbf{Y}_{\mathrm{it}-\mathrm{l}}+\gamma_{2 \mathrm{t}} \mathbf{Y}_{\mathrm{it}-2}+\mathbf{u}_{\mathrm{it}}$

\begin{tabular}{|c|c|c|c|c|c|c|c|}
\hline \multirow{3}{*}{$\begin{array}{c}\text { Period } \\
\text { (t) }\end{array}$} & \multicolumn{6}{|c|}{ Firm Profitability } & \multirow{3}{*}{ GSTAT } \\
\hline & \multicolumn{2}{|c|}{ Upper $25 \%$} & \multicolumn{2}{|c|}{ Middle 50\% } & \multicolumn{2}{|c|}{ Lower $25 \%$} & \\
\hline & $\gamma_{1 t}$ & $\gamma_{2 \mathbf{t}}$ & $\gamma_{1 t}$ & $\gamma_{2 t}$ & $\gamma_{1 t}$ & $\gamma_{2 t}$ & \\
\hline 2002 & $0.983^{* 1}$ & 0.021 & $0.833^{* 1}$ & 0.090 & $0.993^{* 1}$ & 0.008 & $15.339 *$ \\
\hline 2003 & $1.018^{* 1}$ & -0.036 & $1.044^{* 1}$ & -0.031 & $1.059^{* 1}$ & -0.050 & 4.937 \\
\hline 2004 & $1.141^{* 1}$ & -0.129 & $0.833^{* 1}$ & $0.171^{*}$ & $1.216^{* 1+}$ & $-0.215^{*}$ & $40.641 *$ \\
\hline 2005 & $1.550 * 1+$ & $-0.562 *$ & $1.261^{* 1+}$ & $-0.333^{*}$ & $1.569^{* 1+}$ & $-0.571^{*}$ & $38.622 *$ \\
\hline 2006 & $1.363^{* 1+}$ & $-0.366^{*}$ & $1.289^{* 1+}$ & $-0.303^{*}$ & $1.374^{* 1+}$ & $-0.380 *$ & $14.647 *$ \\
\hline 2007 & $1.304^{* 1+}$ & $-0.294 *$ & $1.271^{* 1+}$ & $-0.291 *$ & $1.303^{* 1+}$ & $-0.295^{*}$ & 2.123 \\
\hline
\end{tabular}

\section{CONCLUDING REMARKS}

In this empirical study, we attempt to contribute to the accumulating evidence on the issue of firm sizegrowth relation by investigating how profitability would influence this relationship and whether it would imply a qualification of Gibrat's law. To this end, we first divided our sample of 191 firms into three profitability performance groups, depending upon the average size of profitability over the six periods covering the 2000-2007 interval. We employed a dynamic varying coefficients model to examine the impact of firms' profitability performance on their size-growth relation. Within this contest, we estimated the model over six periods using random generalized least squares.

Our pooled RGLS estimation results support the Gibrat's law over the first three periods but imply faster growth for larger firms and/or autocorrelated growth in the other three periods. The same is true in our profitability group-specific estimates of the model as well, with the exception of 2004. Thus, the results support Gibrat's law of random growth process for 2002 and 2003, but imply faster growth for larger firms in the cases of all three profitability groups over 2005, 2006, and 2007. Nevertheless, with the exception of 2003 and 2007, the GSTAT results support the validity of differentiating among the three profitability groups. Overall, the empirical results in 
this study do not lend visible support to the hypothesis that higher profitability creates a differential advantage to the smaller firms in their growth process.

\section{AUTHOR INFORMATION}

Dr. Mukhopadhyay joined Saint Mary's University in 1979, and is a full professor in the Department of Economics since 1992. His publications include book chapters as well as articles in Journal of Industrial Economics, Southern Economic Journal, Eastern Economic Journal, Canadian Public Policy, Management Decision, Managerial Finance, American Journal of Small Business, and Journal of Socio - Economics.

Dr. AmirKhalkhali has been at Saint Mary's University since 1984, and is a full professor in the Department of Economics since 1996. His publications include book chapters and articles in journals such as Canadian Journal of Economics, Canadian Public Administration, Canadian Public Policy, Canadian Tax Journal, Applied Economics, Development Policy Review, Eastern Economic Journal, Economic Modelling, Economic Notes, Empirical Economics, IMF Staff Papers, Journal of Policy Modelling, Southern Economic Journal, Communications in Statistics, Sankhya, Journal of Statistical Computation and Simulation, and The Statistician.

\section{REFERENCES}

1. Almus, M. and E. Nerlinger (2000), 'Testing 'Gibrat's Law' for Young Firms - Empirical Results for West Germany', Small Business Economics, 15, 1-12.

2. AmirKhalkhali, S. and Dar, A., "Testing for Capital Mobility: A Random Coefficients Approach", Empirical Economics, 18, 1993, 523-541.

3. AmirKhalkhali, S. and Mukhopadhyay, A. K., "The influence of Size and RD on the Growth of Firms in the U.S.", Eastern Economic Journal, 19(2), Spring 1993, 223-233.

4. Audretsch, D. B., L. Klomp, E. Santarelli and A. R. Thurik, (2004), 'Gibrat's Law: Are the Services Different?' Review of Industrial Organization 24, 301-324.

5. Beck, Thornsten, et. al., "Financial and Legal Constraints to Growth: Does the Firm Size Matter?", The Journal of Finance, vol. LX no,. 1, Feb 2005

6. Binks, Martin R. and C. T. Ennew, "Growing Firms and the Credit Constraint", Small Business Economics, Vol. 8, no. 1, Feb 1996

7. Bottazzi, G. and A. Secchi, 'Gibrat's Law and diversification', Industrial and Corporate Change 15 (5), 2006, 847-875.

8. Buckley, P.J., Dunning, J.H. and Pearce, R.D., "An Analysis of the Growth and Profitability of the World's Largest Firms. 1972 to 1977". Kyklos. 37(1), 1984, 3-26.

9. Carpenter, Robert E. and Bruce C. Petersen, "Is the Growth of Small Firms Constrained by Internal Finance?", Review of Economics and Statistics, May 2002, Vol. 84, No. 2, pp. 298-309

10. Caves, R. E., "Industrial Organization and New Findings on the Turnover and Mobility of Firms", Journal of Economic Literature, 36(4), December 1998, 141-149.

11. Chesher, A., "Testing the Law of Proportionate Effect". Journal of Industrial Economics, June 1979, 403-11.

12. Coad, Alex, "Firm Growth: A Survey", Manuscript, Max Plank Institute of Economics, May 14, 2007

13. Cowling, M.. "The Growth - Profit Nexus." Small Business Economics 22, 2004, 1-9.

14. Del Monte, A. and Papagni, E.M, 'R\&D analysis and the growth of firms: empirical analysis of a panel of Italian firms', Research policy, 32(6), June 2003, 1003-10014.

15. Droucopoulos, V., "International Big Business, 1957-77: A Sequel on the Relationship Between Size and Growth". Journal of Economic Studies. 9(3), 1982, 3-19.

16. Droucopoulos, V., "International Big Business Revisited: On the Size and Growth of the World's Largest Firms". Managerial Decision Economics. Dec. 1983, 244-52.

17. Gibrat, R., Les inegalites economiques, Paris: Librairie du Receuil Sirey, 1931.

18. Hall B.H., "The relationship between firm size and firm growth in the US manufacturing sector". The Journal of Industrial Economics. June 1987, 583-606.

19. Hart, P. E. and Oulton, N., "Growth and Size of Firms", Economic Journal, September 1996, 1242-1252.

20. Ijiri, Y. and Simon, H. A., "Interpretations of Departures from the Pareto Curve Firm-Size Distributions", Journal of Political Economy, March/ April 1974, 315-31. 
21. Kumar, M.S., "Growth, Acquisition Activity and Firm Size: Evidence from the United Kingdom". Journal of Industrial Economics. March 1985, 327-38.

22. Marris, R., "The Economic Theory of Managerial Capitalism" Macmillan: London, 1964.

23. Marris, R and D. C. Mueller, "The Corporation, Competition, and the Invisible Hand", Journal of Economic Literature, Vol. XVIII (March 1980), pp. 32-63.

24. Mueller, Dennis, "The Persistence of Profits Above the Norm", Economica, 44, 1977, 369-380

25. Mukhopadhyay A.K. and AmirKhalkhali, S., 'Technological opportunity and the growth process of firms', Journal of Academy of Business and Economics, 3(1), 2004, 111-116.

26. Penrose, Edith, The theory of the growth of the firm, Oxford University Press, 1959

27. Pratt, J. W. and Schlaifer, R., "On the Nature and Discovery of Structure", Journal of the American Statistical Association, March 1984, 9-33.

28. Pratt, J. W. and Schlaifer, R., "On the Interpretation and Observation of Laws", Journal of Econometrics, September 1988, 23-52.

29. Schumpeter, J.A., Capitalism, Socialism and Democracy, Third Edition, George Allen \& Unwin, London, 1950.

30. Shepherd, W. G, "Causes of Increased Competition in the U.S. Economy, 1939-1980", The Review of Economics and Statistics, Vol. 64, No. 4 (Nov., 1982), pp. 613-626.

31. Sutton, John, "Gibrat's Legacy", Journal of Economic Literature 35, March 1997, 40-59.

32. Swamy, P.A.V.B., "Efficient Inference in a Random Coefficients Regression Model", Econometrica, March 1970, 311-23.

33. Swamy, P.A.V.B. and Mehta, J.S., "Bayesian and Non-Bayesian Analysis of Switching Regressions and of Random Coefficient Regression Models", Journal of the American Statistical Association, September 1975, 593-602.

34. Swamy, P.A.V.B. and Tavlas, G.S., Random Coefficient Models: Theory and Applications, Journal of Economic Surveys, 2002, 165-196.

35. Swamy, P.A.V.B., and Tavlas, G.S., "Random Coefficient Models". In: Baltagi, B.H. (Ed.) Companion to Theoretical Econometrics, Basil Blackwell, 2002, 410-428.

36. Vining, D. R. Jr., "Autocorrelated Growth Rates and the Pareto Law: A Further Analysis", Journal of Political Economy, April 1976, 369-80. 